\title{
NOTE ON THE ACTION OF ALCOHOLIC POTASH ON HEPTYLENE BROMIDE.
}

\author{
F. P. VhNabi.e, Phi, D.,
}

Having on band a small supply of heptylene bromide, described in this journal (IV.22), the action of an alcoholic solution of potassium hydrate was tried upon it with a view to the formation of a bydrocarbon with two less carbon atoms a heptine isomeric with the oenanthylidene of Limpricht (Liebig's Annalen 103.81) and the tetra methylallylene of Henry (Ber. Chem. Ges. 8. 400). These two bodies were formed by the action of alcoholic potash on the chlorides. It was interesting then to see if the reaction with this bromide would follow the same course.

From seven to eight grammes of heptylene bromide were placed in a flask and an excess of a strong alcoholic solution of caustic potash added ( 2 mol. $\mathrm{KOH}$ to $1 \mathrm{~mol}, \mathrm{C}_{4} \mathrm{H}_{14} \mathrm{Br}_{2}$ being the proportion required by formula). To condense and return the alcohol to the flask it was connected with an upright condenser. The reaction commenced immediately in the cold-potassium bromide beginning to deposit-but it went on very slowly without the aid of heat. The whole was accordingly heated 4-6 hours on a water bath, the potassium salt forming a thick deposit on the sides of the flank and the liquid, at first colorless, darkening to a reddish black. At the expiration of this time no further precipitation of potassium bromide was observable on adding fresh alcoholic potash. The oily liquid was thoroughly wanhed with water, separating in a lighter layer at the top of the separating funnel, was dried over calcium chloride and finally fractioned under $100^{\circ} \mathrm{C}$, the amount coming over was small. The thermometer the rose rapidly to $150^{\circ} \mathrm{C}$. then slowly to $160^{\circ} \mathrm{C}$. Between these two degrees nearly the whole product came over, leaving a dirty, thick mass behind in the fractioning flask. On redistilling the fraction from $150^{\circ}-160^{\circ} \mathrm{C}$, a small portion of a constant-boiling product was obtained-boiling at $156^{\circ}$ $158^{\circ} \mathrm{C}$. This was immediately sealed in a tube and set aside for analysis. On examining it qualitatively, bromine was found present in considerable amount so that clearly some brominated compound instead of the expected $\mathrm{C}_{7} \mathrm{II}_{12}$ had been formed by the reaction, Seeing that Bruylaut (Ber. Chem. Ges. 8. 409) had prepared a monobromœnanthylene by the action of alcoholic potash on oenanthylene bromide (hented together two days in closed tubes), a 
bromine determination was made after the method of Carius to see if some similar body had not been found in this case. A confirmatory determination would have been made but unfortunately part of the liquid was lost.

$0.1895 \mathrm{grm}$. substance gave $0.2019 \mathrm{grm}$. silver bromide.

Calculated for $\mathrm{C}_{1} \mathrm{H}_{13} \mathrm{I3r}, 45.19$ per cent. $\mathrm{Br}$-found 45.34 per cent. Probably the first small fraction coming over somewhat under $100^{\circ}$ consisted of $\mathrm{C}_{7} \mathrm{H}_{12}$ but the quantity was too small for examination and purification. The reaction then, instead of following the formula, $\mathrm{C}_{7} \mathrm{H}_{14} \mathrm{Br}_{2} 2 \mathrm{KOH}=\mathrm{C}_{7} \mathrm{H}_{12}+\mathrm{KBr}+2 \mathrm{H}_{2} \mathrm{O}$ was rather $\mathrm{C}_{7} \mathrm{H}_{14} \mathrm{Br}_{2}+$ $\mathrm{KOH}=\mathrm{C}_{2} \mathrm{H}_{13} \mathrm{Br}+\mathrm{KBr}+\mathrm{H}_{2} \mathrm{O}$ in spite of the excess of alcoholic potash.

Brombeptylene- $\mathrm{C}_{7} \mathrm{H}_{13} \mathrm{Br}$ is a colorless mobile liquid, with a pleasant though pungent aromatic odor, lighter than water and boiling at $156^{\circ}-158^{\circ} \mathrm{C}$. The two bodies $\mathrm{C}_{7} \mathrm{H}_{13} \mathrm{Br}$, and $\mathrm{C}_{7} \mathrm{H}_{12}$, prepared by Bruylaut had respectively the boiling points $165^{\circ} \mathrm{C}$ and $100^{\circ} \mathrm{C}$. This gives a difference of $7^{\circ}-9^{\circ}$ in boiling points between the derivation from the cenanthal beptane and the Pinus Sabiniana heptane. Nearly the same difference is noticed between the heptylic bromides $\mathrm{C}_{7} \mathrm{H}_{15} \mathrm{Br}$ from ananthal boiling at $178.5^{\circ}$ and from P. Sabiniana boiling at $165.5^{\circ}$

University of North Carolina.

\section{NOTES FROM THE CHEMICAL LABORATORY OF THE UNIVERSITY OF NORTH CAROLINA-ANALYSI- OF ROCK-SALT FROM SALTVILLE, WASHINGTON $८ O$, VA.}

\section{By Thomas Radcliffe.}

A specimen of this rock-salt sent by the superintendent of the salt-works in the valley of the Holston, yielded on analysis some. what different results from the previously published analysis (Chem News No. 1038) and in view of this and the claim made for this Virginia brine, that it exceeds in purity nearly all others of which analyses are on record, the analysis made in this laboratory is pub. lished. The specimen was brownish-red in color, with a crystalline structure and was obtained whilst deepening one of the salt-wells. This rock-salt is not mined, the brine alone being used for the manufacture of salt. The capacity of the works is at present 450,000 